Love, Inc. 



\title{
Love, Inc.
}

\section{Dating Apps, the Big White Wedding, and Chasing the Happily Neverafter}

\author{
Laurie Essig
}

\section{甲}


University of California Press, one of the most distinguished university presses in the United States, enriches lives around the world by advancing scholarship in the humanities, social sciences, and natural sciences. Its activities are supported by the UC Press Foundation and by philanthropic contributions from individuals and institutions. For more information, visit www.ucpress.edu.

University of California Press

Oakland, California

(C) 2019 by Laurie Essig

Library of Congress Cataloging-in-Publication Data

Names: Essig, Laurie, author.

Title: Love, Inc. : dating apps, the big white wedding, and chasing the happily neverafter / Laurie Essig.

Description: Oakland, California : University of California Press, [2019] | Includes bibliographical references and index. | Description based on print version record and CIP data provided by publisher; resource not viewed.

Identifiers: LCCN 2018034895 (print) | LCCN 2018038243 (ebook) | ISBN 9780520967922 (epub and ePDF) | ISBN 9780520295018 (cloth : alk. paper) ISBN $978052030049 \mathrm{I}$ (pbk. : alk. paper)

Subjects: LcsH: Love-Social aspects. HappinessSocial aspects. | Economics-Sociological aspects. Classification: LCC BF575.L8 (ebook) | LCC BF575.L8 E83 2019 (print) | DDC I52.4/I- dc23

LC record available at https://lccn.loc.gov/20I8034895

Manufactured in the United States of America
$\begin{array}{llllllll}26 & 25 & 24 & 23 & 22 & 2 \mathrm{I} & 20 & \text { I9 }\end{array}$

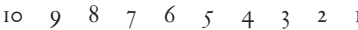


For my daughters, Willa and Georgia.

I have always loved you both without question. 
